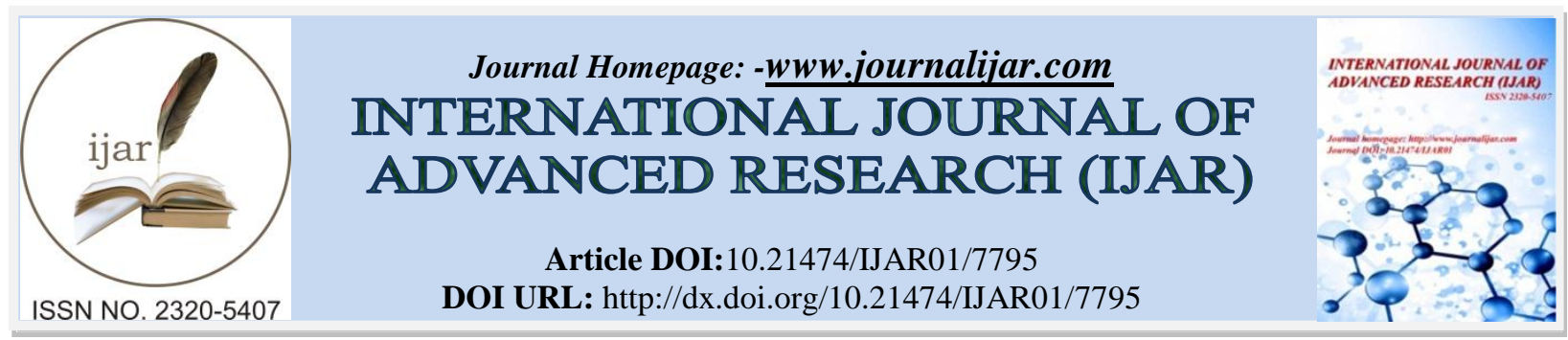

RESEARCH ARTICLE

\title{
QUALITATIVE ANALYSIS OF LACTOBACILLUS STRAINS IN MILK PROBIOTICS
}

\section{Md. Hamiduzzaman ${ }^{1}$, Fayad Bin Abdus Salam ${ }^{1}$, A. H. M. Nazmul Hasan ${ }^{1}$ and Sayma Afroz Santa ${ }^{2}$}

1. Assistant Professor, Department of Pharmacy, University of Asia Pacific, Bangladesh

2. Master of Public Health, Daffodil International University, Bangladesh

\section{Manuscript Info}

\section{Manuscript History}

Received: 2 August 2018

Final Accepted: 4 September 2018

Published: October 2018

Keywords:

Probiotics, Lactobacillus, biochemical tests, sugar \& milk fermentation test, salt $\& \mathrm{pH}$ tolerance test.

\begin{abstract}
In the present study, an attempt was taken for qualitative analysis (to detect the presence) of Lactobacillus strains: one of the major bacterial strains of milk probiotics by different biochemical tests, salt \& $\mathrm{pH}$ tolerance and subsequently sugar \& casein fermentation tests of cheese, curd and milk kefir. Gram staining and colony morphology of each isolated bacterial colony primarily indicated the presence of Lactobacillus species which was further confirmed by different biochemical and selective tests for Lactobacillus species. Negative catalase test as well as positive Kilger's iron agar, oxidase and Simon citrate as biochemical tests confirmed the presence of Lactobacillus species in the test samples. Additionally, good to moderate sugar (sucrose, fructose, glucose \& lactose) and skim milk fermentation revealing deep red color and clear zone appeared around the areas in the medium where the organism had grown, proved the presence of Lactobacillus species in the samples. Moreover, less growth or absence of bacteria in MRS broth medium containing higher salt concentration $(8 \% \mathrm{NaCl}$ solution and above) and having higher $\mathrm{pH}$ value by adding $1 \mathrm{~N} \mathrm{HCl}$ ( $\mathrm{pH} 3$ and above) finally confirmed that cheese, curd and milk kefir contain Lactobacillus species.
\end{abstract}

Copy Right, IJAR, 2018,. All rights reserved.

\section{Introduction:-}

Probiotics termed as live micro-organisms mainly good bacteria that primarily lined in the gut upon administration in adequate amounts in our body confers a health benefit to the host [1]. Roberfroid reported that today's most of the foods contain little to no probiotics, on the contrary they contain antibiotics which kill off the good bacteria in our bodies because of refrigeration and dangerous agricultural practices. Thus adding more probiotic in foods can ensure stronger immune system, improved digestive system, reduction of cold \& flu, healing from leaky gut \& inflammatory bowel disease, better breath, healthier skin and vitamin production [2].

Most of the probiotics contain Lactobacillus, Bifidobacterium, Bacillus and Streptoccocus species in their formulation and milk derived probiotics are predominant with Lactobacillus species: these species are responsible for producing lactase, the enzyme required to break down lactose (the sugar in milk) and ferment carbohydrates in the gut producing lactic acid which helps to create an acidic environment in the digestive tract discouraging many unwanted microorganisms that thrive in an alkaline environment [3]. The genus Lactobacillus is gram positive, nonspore-forming, usually catalase-negative, non-motile and facultative anaerobic bacteria. It is also very heterogeneous, encompassing species with a large variety of phenotypic, biochemical and physiological properties. 
In recent decades, extensive research has been carried out on isolation and screening of microorganisms from traditional fermented foods and lactic acid bacteria (LAB) and yeasts playing an important role in numerous natural food fermentations such as curd, cheese, pickles and various other traditional foods which are closely associated with the human environment [4] and these organisms have also gained popularity as probiotics [5].

As lactic acid bacteria is regarded as a major group of probiotic bacteria, this study aimed to isolate and identify Lactobacillus species from milk probiotics by following different standard protocols.

\section{Methods and Materials:-}

\section{Sample collection:-}

Raw and processed cheese, sweet and sour curd, milk and coconut kefir (each 2 samples) were collected in sterile polythene bags from different markets at Dhaka city of Bangladesh (Table 1). After collection, all samples were labeled appropriately and kept in the insulated box and transported to the laboratory. All samples were processed within 24 hours form the time of collection.

Table 1:-List of collected samples

\begin{tabular}{|c|c|c|c|c|}
\hline SL. No & Sample code & Sample & Sample type & Sources \\
\hline 1 & $\mathrm{HCR}_{1}$ & Cheese & Raw & Gazipur, Dhaka \\
\hline 2 & $\mathrm{HCR}_{2}$ & & Farmgate, Dhaka \\
\hline 3 & $\mathrm{HCP}_{1}$ & & Azimpur, Dhaka \\
\hline 4 & $\mathrm{HCP}_{2}$ & \multirow{2}{*}{ Curd } & \multirow{2}{*}{ Sweet } & Uttura, Dhaka \\
\hline 5 & $\mathrm{HDR}_{1}$ & \multirow{2}{*}{ Curd } & Sour & Mirpur, Dhaka \\
\hline 6 & $\mathrm{HDR}_{2}$ & & Dhanmondi, Dhaka \\
\hline 7 & $\mathrm{HDP}_{1}$ & Milk & Processed & Shyamoli, Dhaka \\
\hline 9 & $\mathrm{HDP}_{2}$ & Kefir & & Motijheel, Dhaka \\
\hline 10 & $\mathrm{HKP}_{1}$ & & Savar, Dhaka \\
\hline
\end{tabular}

\section{Sample preparation:-}

All of the collected samples (both raw \& processed) were prepared for further analysis. In order to prepare ready sample, $1 \mathrm{gm}$ of each sample were taken into 9ml MRS (Man, Rogosa and Sharpe) broth containing test tube and mixed well using vortex machine. The entire sample containing test tubes were then incubated for 24 hours at $37^{\circ} \mathrm{C}$ and finally preserved the samples for further analysis.

\section{Sample enrichment:-}

RMS agar plates were prepared and one loop of broth solution containing bacteria from each test tube was taken and inoculated on plates. Then plates were incubated for 24 hours at $37^{\circ} \mathrm{C}$ for optimum bacterial growth.

\section{Single colony isolation from enriched samples:-}

After 24 hours, all incubated RMS agar [6] (Table 2) plates were analyzed by naked eye to identify the morphology of bacteria grown on those plates. Suspected characteristic single colony was isolated and colony morphology was recorded. Finally MRS slants were prepared and all of the suspected bacterial colonies were stored separately.

Table 2:-Composition of RMS broth medium (up to $1000 \mathrm{ml}$ water)

\begin{tabular}{|l|c|}
\hline \multicolumn{1}{|c|}{ Name of ingredients } & Amount \\
\hline Peptone & $10.0 \mathrm{gm}$ \\
\hline Beef extract & $10.0 \mathrm{gm}$ \\
\hline Sodium chloride & $5.0 \mathrm{gm}$ \\
\hline $\mathrm{pH}$ after sterilization & $7.3 \pm 0.1$ \\
\hline
\end{tabular}

\section{Qualitative analysis:-}

\section{Gram staining of isolated bacterial colony:-}

In an aseptic area, under laminar air flow a drop of saline water was placed on the slide and then a colony kept in RMS slant was taken and made a suspension on the slide to obtain thin smear. Finally smear was fixed with slight heating of the slide that was flooded with crystal violet solution and kept for 01 minute subsequently washed out 
with running tap water. Smear was covered with a few drop of Gram's Iodine and kept for about 1 minute. Resultant slide was then washed out with running tap water. The slide was decolorized with absolute alcohol and then it was kept for 30 seconds and washed out with running tap water. Again alcohol was poured on the slide for a while followed by washing was continued till color ceases coming out. After de-colorization the slide was cover with a few drop of safranin red for 2 minutes and then washed out with running tap water [7]. After air drying of the slides at room temperature, a drop of emersion oil was given over the dried slide to observe color under the high power objective lenses (x100).

\section{Biochemical tests of the samples:- \\ Catalase Test:-}

The catalase test of the samples was performed by using $3 \%$ hydrogen peroxide $\left(\mathrm{H}_{2} \mathrm{O}_{2}\right)$ solution. A drop of hydrogen peroxide (3\%) was placed on a sterile glass slide. A drop of bacterial sample (kept in RMS broth) was placed on the slide and mixed well with the help of sterile loop. After few minutes slide was examined to detect the presence of bubble or froth on the slide. A positive and a negative control were used as E.coli and Staphylococcus aureus respectively [8].

\section{Kilger's Iron agar (KIA) test:-}

KIA test performs to know the mode of dextrose utilization by bacteria in oxidative/fermentative test. Kligler Iron Agar combines the principles of Russell double sugar medium and lead acetate agar into one medium (Table 2). This combination permits differentiation of bacilli by their ability to ferment dextrose or lactose, which produces color changes of the $\mathrm{pH}$ indicator (phenol) in response to acid production during fermentation of the sugars. Slants of KIA media were inoculated by stabbing the butt and streaking the slant with 24 hours culture. After incubation at $37^{\circ} \mathrm{C}$ for 18-24 hours, results were recorded for changing in color of the butt or slant, $\mathrm{H}_{2} \mathrm{~S}$ or other gas production [9].

Table 3:-Composition of Kilger's Iron agar (up to $1000 \mathrm{ml}$ water)

\begin{tabular}{|l|c|}
\hline \multicolumn{1}{|c|}{ Name of ingredients } & Amount \\
\hline Peptone & $15.0 \mathrm{gm}$ \\
\hline Lactose & $10.0 \mathrm{gm}$ \\
\hline Proteose Peptone & $5.0 \mathrm{gm}$ \\
\hline Sodium Chloride & $5.0 \mathrm{gm}$ \\
\hline Beef Extract & $3.0 \mathrm{gm}$ \\
\hline Yeast Extract & $3.0 \mathrm{gm}$ \\
\hline Dextrose & $1.0 \mathrm{gm}$ \\
\hline Sodium Thiosulfate & $0.3 \mathrm{gm}$ \\
\hline Ferrous Sulfate & $0.2 \mathrm{gm}$ \\
\hline Phenol Red & $0.024 \mathrm{gm}$ \\
\hline Agar & $12.0 \mathrm{gm}$ \\
\hline \multicolumn{2}{|c|}{ Final $\mathrm{pH} 7.4 \pm 0.2$ at $25^{\circ} \mathrm{C}}$. \\
\hline
\end{tabular}

\section{Oxidase test:-}

Oxidase test of all samples was performed on a piece of sterile what man filter paper which was soaked with $1 \%$ solution of $\mathrm{N}, \mathrm{N}, \mathrm{N}^{1} \mathrm{~N}^{1}$-Tetramethy1-p-phenylenediamine solution. A portion of the colony of the test organism was picked up with a sterile stick and touched on to the paper with impregnated reagent. After 5 to 10 second, the filter paper was examined to observe the color change occurred [10].

\section{Simmon citrate test:-}

Isolated bacterial colony was immersed in Simmon's citrate agar slants. Then slants were kept for incubation of 2448 hours at $37^{\circ} \mathrm{C}$ and growth of bacteria and color change (to blue) was observed [11].

Table 4:-Composition of Simmon Citrateagar (up to $1000 \mathrm{ml}$ water)

\begin{tabular}{|l|c|}
\hline \multicolumn{1}{|c|}{ Name of ingredients } & Amount \\
\hline Sodium Chloride $(\mathrm{NaCl})$ & $5.0 \mathrm{gm}$ \\
\hline Sodium Citrate (dehydrate) & $2.0 \mathrm{gm}$ \\
\hline Ammonium Dihydrogen Phosphate & $1.0 \mathrm{gm}$ \\
\hline Dipotassium Phosphate & $1.0 \mathrm{gm}$ \\
\hline
\end{tabular}




\begin{tabular}{|l|c|}
\hline Magnesium Sulfate (heptahydrate) & $0.2 \mathrm{gm}$ \\
\hline Bromothymol Blue & $0.08 \mathrm{gm}$ \\
\hline Agar & $15.0 \mathrm{gm}$ \\
\hline \multicolumn{2}{|c|}{} \\
\hline
\end{tabular}

\section{Sugar fermentation test:-}

Sugar fermentation test of all samples was performed using fructose, sucrose, glucose and lactose. At first, the sugar was dissolved in distill water to make $1 \% \mathrm{~W} / \mathrm{V}$ solution. MRS broth was prepared and added respective $1 \%$ W/V sugar solution. Then phenol red indicator was added in the broth solution which turns the color of broth solution into dark red. $10 \mathrm{ml}$ media was dispensed and Darham's tube was inserted in each of these test tubes. Then the final mixture of broth and sugar solution with Darham's tube was sterilized in autoclave for 20 minutes at $121^{\circ} \mathrm{C}$. After autoclaving the solution was cooled and bacterial sample was inoculated in test tubes. Then test tubes were incubated for $24 \mathrm{~h}$ at $37^{\circ} \mathrm{C}$ where only media was used as negative control. Results were observed by color changing and gas formation [12].

\section{Salt tolerance test:-}

In order to perform salt tolerance test of the samples, MRS broth containing $2 \%, 4 \%$ and $8 \% \mathrm{NaCl}$ solution were prepared. Then $5 \mathrm{ml}$ of the media was dispensed in test tube and sterilized in autoclave at $121^{\circ} \mathrm{C}$ for 20 minutes. After autoclaving, the solution was cooled down and each bacterial sample was inoculated in three test tubes containing $2 \%, 4 \%$ and $8 \% \mathrm{NaCl}$ broth solution and kept for incubation at $37^{\circ} \mathrm{C}$ for 24 hours. After 24 and 48 hours microbial growth was determined by observing turbidity of the MRS broth medium [13].

\section{pH tolerance test:-}

In order to perform $\mathrm{pH}$ tolerance test, MRS broth was prepared and $\mathrm{pH}$ was adjusted to 2, 3, 4, 6, 8 and 10 and the adjusted broth was dispensed in 6 test tubes (each $5 \mathrm{ml}$ ). These test tubes were sterilized in autoclave in $121^{\circ} \mathrm{C}$ for 20 minutes. Samples were inoculated in each test tube and incubated for 24 hours at $37^{\circ} \mathrm{C}$ where media was used as negative control [14].

\section{Casein digestion test:-}

In order to perform casein digestion test, $1 \%$ skim milk agar plate was prepared and sterilized by autoclaving for 20 minutes at $121^{\circ} \mathrm{C}$. Then bacterial samples were inoculated with streaking and incubated for 24 hours at $37^{\circ} \mathrm{C}$. After 24 hours, clear zone on skim milk agar plate was observed indicating the positive result [15].

\section{Result and Discussion:-}

In this study processed, raw, sweet and sour type of milk probiotics (cheese, curd \& kefir) were subjected for different biochemical tests along with sugar fermentation, salt, $\mathrm{pH}$ tolerance and casein digestion tests for qualitative analysis of Lactobacillus species.

\section{Identification of isolated bacterial colony:- Colony morphology:-}

Total ten morphologically distinct single colonies were isolated from four cheeses samples (raw \& processed), four curds samples (raw \& processed) and two milk kefir samples (processed) on MRS plates (Table 5 and Figure 1). All the isolates were gram positive bacteria with rod shaped structure (Figure 2).

Table 5:-Observation of colony morphology

\begin{tabular}{|c|c|c|c|c|c|c|c|}
\hline \multirow{2}{*}{$\begin{array}{l}\text { SL. } \\
\text { No }\end{array}$} & \multirow{2}{*}{$\begin{array}{c}\text { Sample } \\
\text { code }\end{array}$} & \multirow[t]{2}{*}{ Sample } & \multirow{2}{*}{$\begin{array}{c}\text { Sample } \\
\text { type }\end{array}$} & \multicolumn{4}{|c|}{ Morphology of colony } \\
\hline & & & & Shape & Size & Color & Number \\
\hline 1 & $\mathrm{HCR}_{1}$ & \multirow[t]{2}{*}{ Cheese } & \multirow[t]{2}{*}{ Raw } & \multirow[t]{2}{*}{ Round, Centered } & \multirow[t]{2}{*}{ Small } & \multirow[t]{2}{*}{ Pale Yellow } & \multirow[t]{2}{*}{ Plenty } \\
\hline 2 & $\mathrm{HCR}_{2}$ & & & & & & \\
\hline 3 & $\mathrm{HCP}_{1}$ & \multirow[t]{2}{*}{ Cheese } & \multirow[t]{2}{*}{ Processed } & \multirow[t]{2}{*}{ Round, Centered } & \multirow[t]{2}{*}{ Small } & \multirow[t]{2}{*}{ Pale Yellow } & \multirow[t]{2}{*}{ Plenty } \\
\hline 4 & $\mathrm{HCP}_{2}$ & & & & & & \\
\hline 5 & $\mathrm{HDR}_{1}$ & \multirow[t]{2}{*}{ Curd } & \multirow[t]{2}{*}{ Sweet } & \multirow[t]{2}{*}{ Round, Centered } & \multirow[t]{2}{*}{ Small } & \multirow[t]{2}{*}{ Pale Yellow } & \multirow[t]{2}{*}{ Plenty } \\
\hline 6 & $\mathrm{HDR}_{2}$ & & & & & & \\
\hline 7 & $\mathrm{HDP}_{1}$ & \multirow[t]{2}{*}{ Curd } & \multirow[t]{2}{*}{ Sour } & \multirow[t]{2}{*}{ Round, Centered } & \multirow[t]{2}{*}{ Small } & \multirow[t]{2}{*}{ Pale Yellow } & \multirow[t]{2}{*}{ Plenty } \\
\hline 8 & $\mathrm{HDP}_{2}$ & & & & & & \\
\hline
\end{tabular}




\begin{tabular}{|c|c|c|c|c|c|c|c|}
\hline 9 & $\mathrm{HKP}_{1}$ & Milk Kefir & Processed & Round, Centered & Small & Pale Yellow & Plenty \\
\hline 10 & $\mathrm{HKP}_{2}$ & & & & & \\
\hline
\end{tabular}

\section{Gram staining:-}

All isolated single colony bacteria were subjected for gram staining test and all sample revealed positive result. All isolates were morphologically in rod shape (Table 6 \& Figure 2) which represents Lactobacillus species present in these samples.

Table 6:-Observation of gram staining

\begin{tabular}{|c|c|c|c|c|c|}
\hline \multirow{2}{*}{$\begin{array}{l}\text { SL. } \\
\text { No }\end{array}$} & \multirow[t]{2}{*}{ Sample code } & \multirow[t]{2}{*}{ Sample } & \multirow[t]{2}{*}{ Sample type } & \multicolumn{2}{|c|}{ Gram staining } \\
\hline & & & & Observation & Morphology \\
\hline 1 & $\mathrm{HCR}_{1}$ & \multirow[t]{2}{*}{ Cheese } & \multirow[t]{2}{*}{ Raw } & \multirow{2}{*}{+} & \multirow{2}{*}{ Rod } \\
\hline 2 & $\mathrm{HCR}_{2}$ & & & & \\
\hline 3 & $\mathrm{HCP}_{1}$ & \multirow[t]{2}{*}{ Cheese } & \multirow[t]{2}{*}{ Processed } & \multirow{2}{*}{+} & \multirow{2}{*}{ Rod } \\
\hline 4 & $\mathrm{HCP}_{2}$ & & & & \\
\hline 5 & $\mathrm{HDR}_{1}$ & \multirow[t]{2}{*}{ Curd } & \multirow[t]{2}{*}{ Sweet } & \multirow{2}{*}{+} & \multirow{2}{*}{ Rod } \\
\hline 6 & $\mathrm{HDR}_{2}$ & & & & \\
\hline 7 & $\mathrm{HDP}_{1}$ & \multirow[t]{2}{*}{ Curd } & \multirow[t]{2}{*}{ Sour } & \multirow{2}{*}{+} & \multirow{2}{*}{ Rod } \\
\hline 8 & $\mathrm{HDP}_{2}$ & & & & \\
\hline 9 & $\mathrm{HKP}_{1}$ & \multirow[t]{2}{*}{ Milk Kefir } & \multirow[t]{2}{*}{ Processed } & \multirow{2}{*}{+} & \multirow{2}{*}{ Rod } \\
\hline 10 & $\mathrm{HKP}_{2}$ & & & & \\
\hline
\end{tabular}

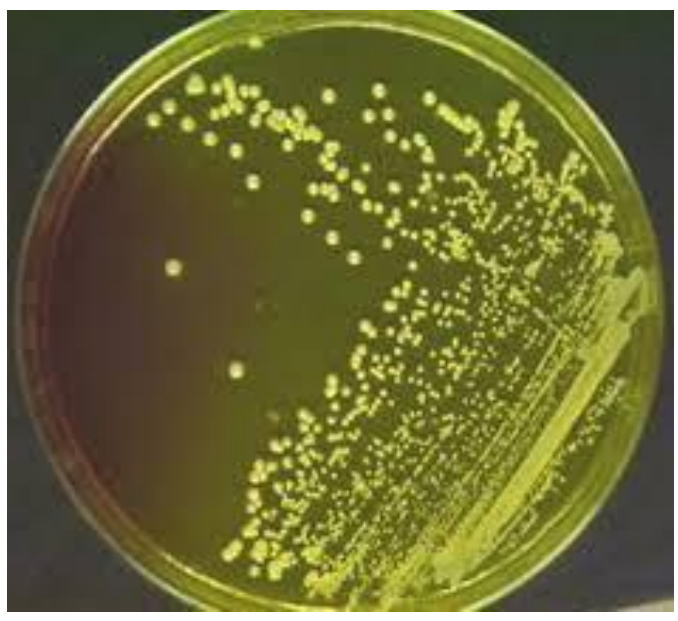

Figure 1:-Colony morphology on MRS plate

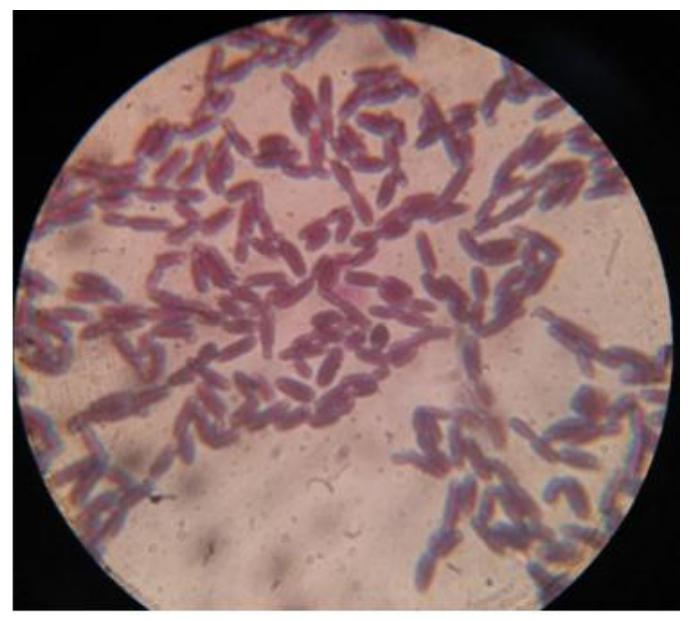

Figure 2:-Gram staining

\section{Biochemical tests of the samples:-}

All the samples were subjected for different biochemical tests like catalase, oxidase, Simon citrate and KIA test for confirmation of Lactobacillus species present in samples.

All of the test samples were catalase negative because no bubble or gas produced due to lower percentage of $\mathrm{H}_{2} \mathrm{O}_{2}$ conversion into water and oxygen (Table 7). Microorganisms can produce catalase enzyme to neutralize toxic forms of oxygen metabolites $\left(\mathrm{H}_{2} \mathrm{O}_{2}\right)$ living in oxygenated environments and protects them. Catalase mediates the breakdown of hydrogen peroxide $\mathrm{H}_{2} \mathrm{O}_{2}$ into oxygen and water. This catalase negative test results indicated the present of Lactobacillus species in milk probiotics tested in this study.

In oxidase test, all samples produced dark purple color within 5-10 second was considered positive for Lactobcillus test where V. cholera was used as positive control (Table7 \& Figure 4). It is known that Simmons citrate agar tests the ability of organisms to utilize citrate as a carbon source. Simmons citrate agar contains sodium citrate as the sole source of carbon, ammonium dihydrogen phosphate as the sole source of nitrogen, nutrients and the $\mathrm{pH}$ indicatorbromothymol blue. Organisms degrading citrate must also use the ammonium salts, producing ammonia [16], thus increasing the $\mathrm{pH}$ of the medium. The increase in $\mathrm{pH}$ then causes color change in the bromothymol blue indicator, 
turning it blue. In case of Simmon Citrate test, all the bacterial isolates (T-1 to T-5 in figure 5) turned the medium color into blue indicated that the organism (Table 7) was citrate positive which confirmed the presence of Lactobacillus species in the test samples. Cheese, curd and milk kefir were subjected to perform KIA test and all initially produced yellow slants and finally converted into red slants with slightly gas production into butt revealed positive result for Lactobacillus species (Table $7 \&$ figure 3 ). Test samples initially produced a yellow slant and butt as a result of dextrose fermentation indicated the acid formation from dextrose and the concentration of dextrose was only one percent and, therefore became rapidly exhausted. Once the dextrose was depleted, the reaction reverts to alkaline (red slant) due to the oxidation of acids. Additionally gas production was demonstrated by the presence of bubbles in the butt or ring formation on the top of the butt indicated the positive result [17].

Table 7:-Results of biochemical tests

\begin{tabular}{|c|c|c|c|c|c|c|c|c|c|c|}
\hline \multirow{3}{*}{$\begin{array}{l}\text { SL. } \\
\text { No }\end{array}$} & \multirow{3}{*}{$\begin{array}{l}\text { Sample } \\
\text { code }\end{array}$} & \multirow[t]{3}{*}{ Sample } & \multirow{3}{*}{$\begin{array}{c}\text { Sample } \\
\text { type }\end{array}$} & \multicolumn{7}{|c|}{ Biochemical tests } \\
\hline & & & & \multirow{2}{*}{$\begin{array}{c}\text { Catalase } \\
\text { test }\end{array}$} & \multirow{2}{*}{$\begin{array}{c}\text { Oxidase } \\
\text { test }\end{array}$} & \multicolumn{3}{|c|}{ Simmon Citrate test } & \multicolumn{2}{|c|}{ KIA test } \\
\hline & & & & & & $24 \mathrm{hr}$ & $48 \mathrm{hr}$ & color & Initial & Final \\
\hline 1 & $\mathrm{HCR}_{1}$ & \multirow[t]{2}{*}{ Cheese } & \multirow[t]{2}{*}{ Raw } & \multirow[t]{2}{*}{-} & \multirow[t]{2}{*}{+} & \multirow[t]{2}{*}{+} & \multirow[t]{2}{*}{+} & \multirow[t]{2}{*}{ Blue } & \multirow{2}{*}{$\begin{array}{l}\text { Yellow/ } \\
\text { acidic }\end{array}$} & \multirow{2}{*}{$\begin{array}{c}\text { Red/ } \\
\text { alkaline }\end{array}$} \\
\hline 2 & $\mathrm{HCR}_{2}$ & & & & & & & & & \\
\hline 3 & $\mathrm{HCP}_{1}$ & \multirow[t]{2}{*}{ Cheese } & \multirow[t]{2}{*}{ Processed } & \multirow[t]{2}{*}{ - } & \multirow[t]{2}{*}{+} & \multirow[t]{2}{*}{+} & \multirow[t]{2}{*}{+} & \multirow[t]{2}{*}{ Blue } & \multirow{2}{*}{$\begin{array}{l}\text { Yellow/ } \\
\text { acidic }\end{array}$} & \multirow{2}{*}{$\begin{array}{c}\text { Red/ } \\
\text { alkaline }\end{array}$} \\
\hline 4 & $\mathrm{HCP}_{2}$ & & & & & & & & & \\
\hline 5 & $\mathrm{HDR}_{1}$ & \multirow[t]{2}{*}{ Curd } & \multirow[t]{2}{*}{ Sweet } & \multirow[t]{2}{*}{ - } & \multirow[t]{2}{*}{+} & \multirow[t]{2}{*}{+} & \multirow[t]{2}{*}{+} & \multirow[t]{2}{*}{ Blue } & \multirow{2}{*}{$\begin{array}{l}\text { Yellow/ } \\
\text { acidic }\end{array}$} & \multirow{2}{*}{$\begin{array}{c}\text { Red/ } \\
\text { alkaline }\end{array}$} \\
\hline 6 & $\mathrm{HDR}_{2}$ & & & & & & & & & \\
\hline 7 & $\mathrm{HDP}_{1}$ & \multirow[t]{2}{*}{ Curd } & Sour & - & + & + & + & Blue & Yellow/ & Red/ \\
\hline 8 & $\mathrm{HDP}_{2}$ & & & & & & & & acidic & alkaline \\
\hline 9 & $\mathrm{HKP}_{1}$ & Milk & Processed & - & + & + & + & Blue & Yellow/ & Red/ \\
\hline 10 & $\mathrm{HKP}_{2}$ & Kefir & & & & & & & acidic & alkaline \\
\hline
\end{tabular}

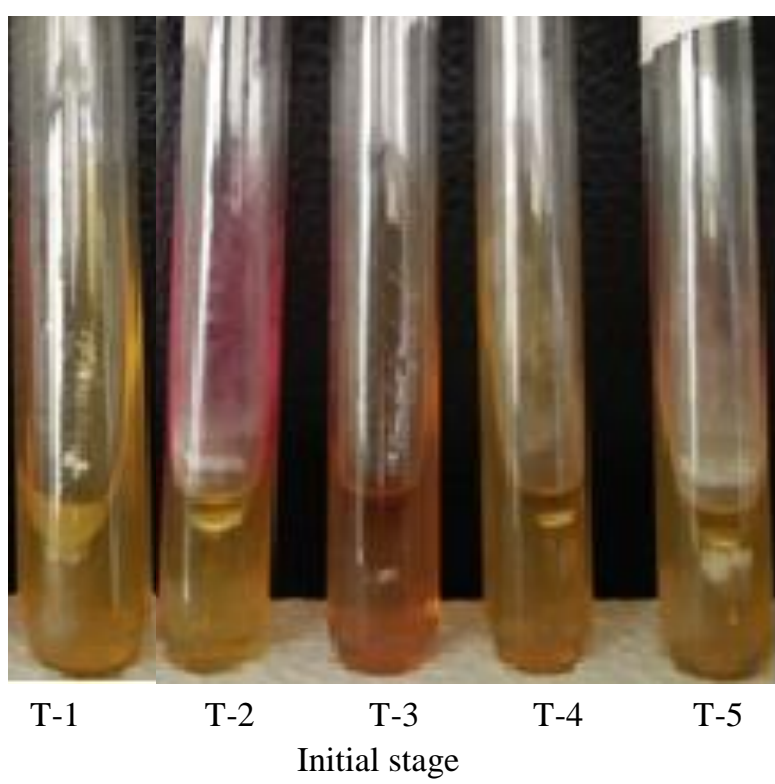

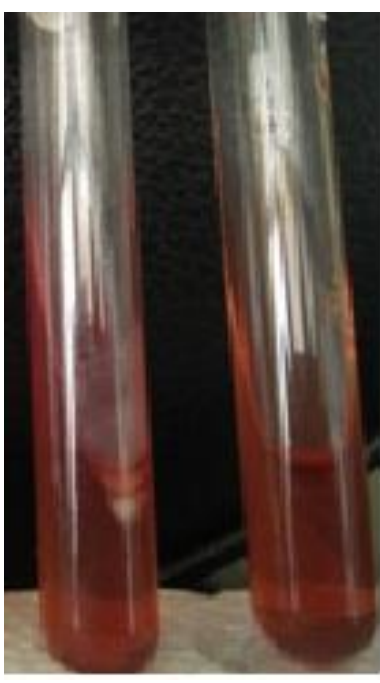

$\mathrm{T}-1$

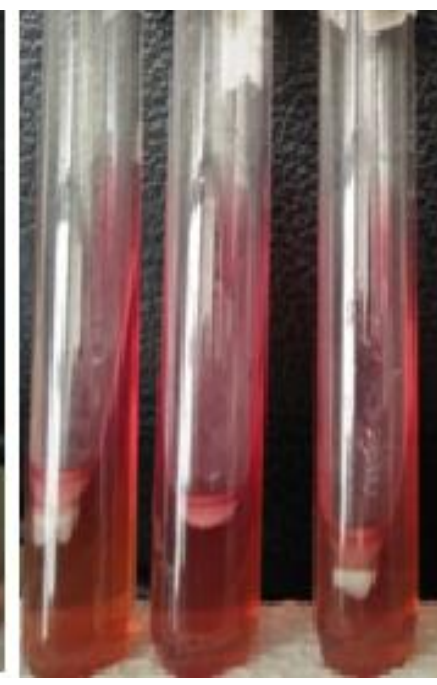

T-3

$\mathrm{T}-5$

Figure 3: KIA test 


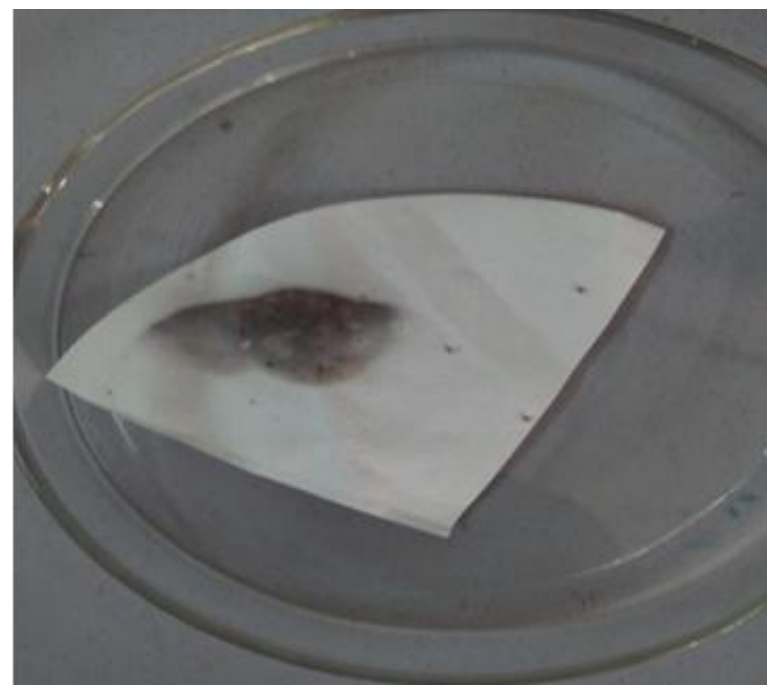

Figure 4: Oxidase test

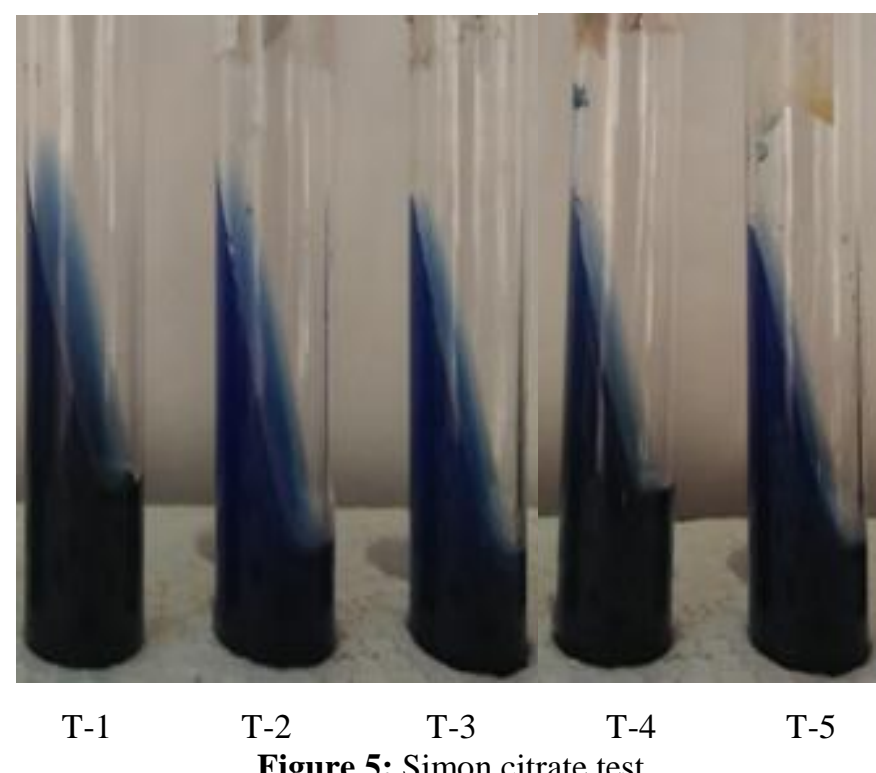

Figure 5: Simon citrate test

\section{Sugar fermentation test:-}

All of the bacterial samples were performed sugar fermentation test in sucrose, fructose, glucose and lactose media. All of the samples performed good fermentation except sour curd and milk kefir revealed moderate fermentation in sucrose; sweet curd and milk kafir performed moderate fermentation in fructose and sour curd and milk kefir showed moderate fermentation in glucose and lactose medium respectively (Table $8 \&$ Figure 6). Due to the lowering of the $\mathrm{pH}$ of the medium because of acid production through fermentation of sugar by the sample was observed by the color change of the $\mathrm{pH}$ indicator-phenol red into deep red in the medium. Additionally small inverted tubes called Durham tubes were also immersed in the medium to test for the production of the gas (hydrogen or carbondioxide). It was observed that all of the test samples produced gas because of different degree of sugar fermentation was an indication for Lactobacillus species [18].

Table 8:-Results of sugar fermentation

\begin{tabular}{|c|c|c|c|c|c|c|c|}
\hline \multirow{2}{*}{$\begin{array}{l}\text { SL. } \\
\text { No }\end{array}$} & \multirow{2}{*}{$\begin{array}{c}\text { Sample } \\
\text { code }\end{array}$} & \multirow[t]{2}{*}{ Sample } & \multirow{2}{*}{$\begin{array}{c}\text { Sample } \\
\text { type }\end{array}$} & \multicolumn{4}{|c|}{ Sugar fermentation } \\
\hline & & & & Sucrose & Fructose & Glucose & Lactose \\
\hline 1 & $\mathrm{HCR}_{1}$ & \multirow[t]{2}{*}{ Cheese } & \multirow[t]{2}{*}{ Raw } & \multirow[t]{2}{*}{$+, \mathrm{r}, \mathrm{g}$} & \multirow[t]{2}{*}{$+, \mathrm{r}, \mathrm{g}$} & \multirow[t]{2}{*}{$+, \mathrm{r}, \mathrm{g}$} & \multirow[t]{2}{*}{$+, \mathrm{r}, \mathrm{g}$} \\
\hline 2 & $\mathrm{HCR}_{2}$ & & & & & & \\
\hline 3 & $\mathrm{HCP}_{1}$ & \multirow[t]{2}{*}{ Cheese } & \multirow[t]{2}{*}{ Processed } & \multirow[t]{2}{*}{$+, \mathrm{y}, \mathrm{g}$} & \multirow[t]{2}{*}{$+, \mathrm{r}, \mathrm{g}$} & \multirow[t]{2}{*}{$+, \mathrm{r}, \mathrm{g}$} & \multirow{2}{*}{$+, \mathrm{r}, \mathrm{g}$} \\
\hline 4 & $\mathrm{HCP}_{2}$ & & & & & & \\
\hline 5 & $\mathrm{HDR}_{1}$ & \multirow[t]{2}{*}{ Curd } & \multirow[t]{2}{*}{ Sweet } & \multirow[t]{2}{*}{$+, \mathrm{r}, \mathrm{g}$} & \multirow[t]{2}{*}{$\pm, \mathrm{y}, \mathrm{g}$} & \multirow[t]{2}{*}{$+, \mathrm{r}, \mathrm{g}$} & \multirow{2}{*}{$+, \mathrm{r}, \mathrm{g}$} \\
\hline 6 & $\mathrm{HDR}_{2}$ & & & & & & \\
\hline 7 & $\mathrm{HDP}_{1}$ & \multirow[t]{2}{*}{ Curd } & \multirow[t]{2}{*}{ Sour } & \multirow[t]{2}{*}{$\pm, \mathrm{y}, \mathrm{g}$} & \multirow[t]{2}{*}{$+, \mathrm{r}, \mathrm{g}$} & \multirow[t]{2}{*}{$\pm, r, g$} & \multirow{2}{*}{$\pm, r, g$} \\
\hline 8 & $\mathrm{HDP}_{2}$ & & & & & & \\
\hline 9 & $\mathrm{HKP}_{1}$ & \multirow[t]{2}{*}{ Milk Kefir } & \multirow[t]{2}{*}{ Processed } & \multirow[t]{2}{*}{$\pm, \mathrm{y}, \mathrm{g}$} & \multirow[t]{2}{*}{$\pm, y, g$} & \multirow[t]{2}{*}{$\pm, y, g$} & \multirow{2}{*}{$\pm, \mathrm{y}, \mathrm{g}$} \\
\hline 10 & $\mathrm{HKP}_{2}$ & & & & & & \\
\hline & $\begin{array}{l}+=\text { Good } \\
\pm=\text { Mode } \\
-=\text { no fe }\end{array}$ & $\begin{array}{l}\text { mentation } \\
\text { fermentat } \\
\text { ntation }\end{array}$ & & $\begin{array}{l}\mathrm{y}=\text { yello } \\
\mathrm{r}=\text { red in } \\
\mathrm{g}=\text { gas } \mathrm{p}\end{array}$ & & & \\
\hline
\end{tabular}




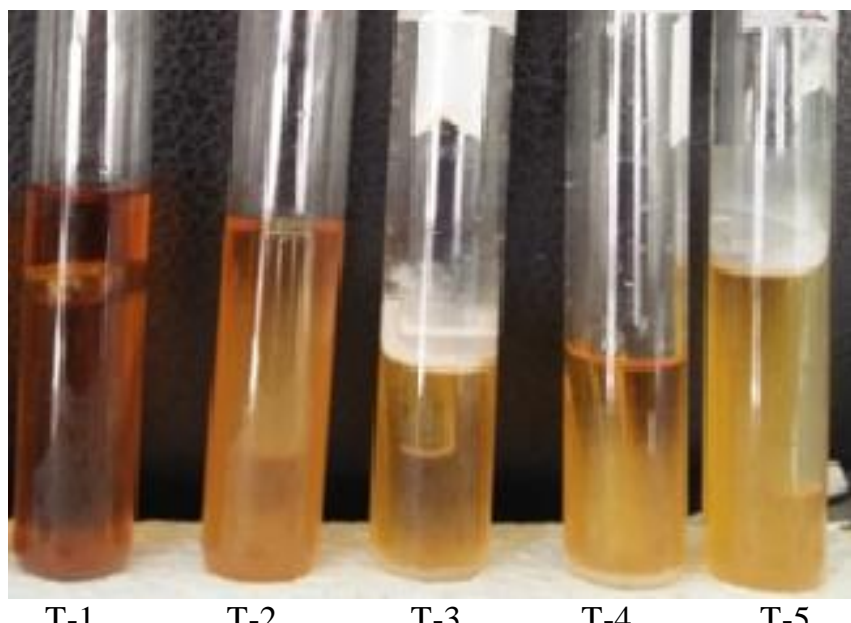

Fructose fermentation

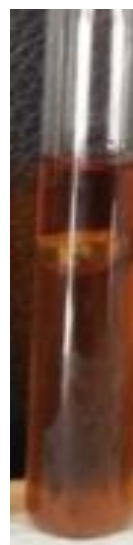

$\mathrm{T}-1$
$\mathrm{T}-2$

$\mathrm{T}-3$

Glucose fermentation

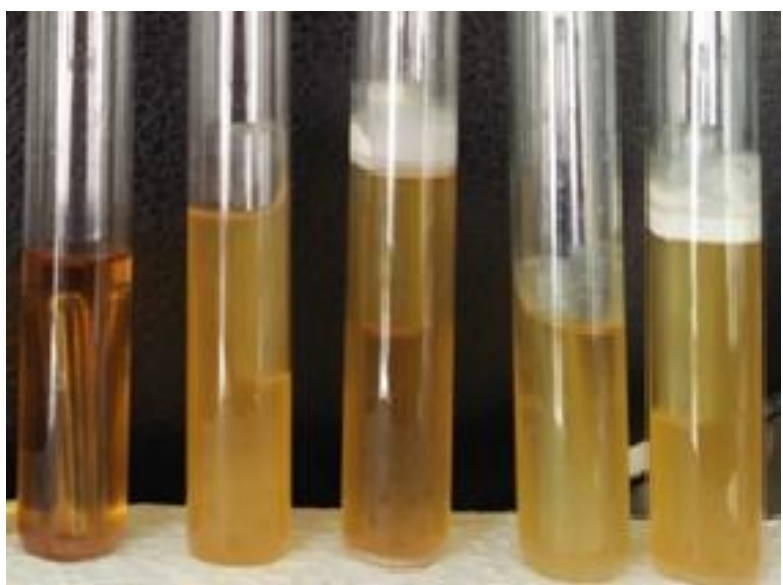

$\mathrm{T}-1$

T-2

$\mathrm{T}-3 \quad \mathrm{~T}-4$

T-5

Sucrose fermentation

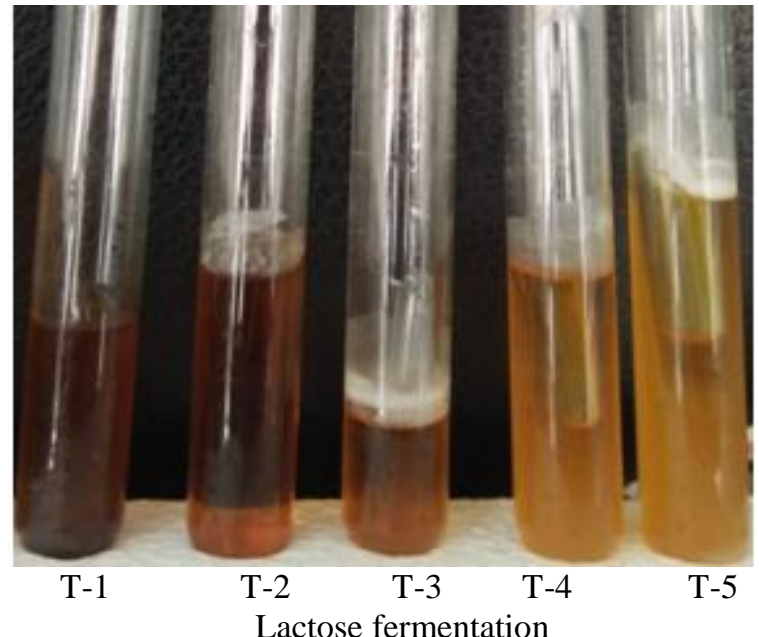

Figure 6: Sugar fermentation

\section{Salt tolerance test:-}

Cheese, curd and milk kefir were performed salt tolerance test at 2\%, 4\% and $8 \%$ salt solution containing MRS broth. As it is a selective medium, this tests the ability of an organism to survive in a salt-rich environment. A positive salt tolerance test was indicated by growth and/or turbidity in media without indicator after 24 and 48 hours in $2 \%$ and $4 \%$ salt medium (Table $9 \&$ Figure 7 ). But in case of $8 \%$ salt solution, there was very less turbidity (less growth of bacteria) and no turbidity (no growth of bacteria) after 48 hours in MRS broth medium [19].

Table 9: Results of salt tolerance test

\begin{tabular}{|c|c|c|c|c|c|c|c|c|c|}
\hline \multirow{3}{*}{$\begin{array}{l}\text { SL. } \\
\text { No }\end{array}$} & \multirow{3}{*}{$\begin{array}{l}\text { Sample } \\
\text { code }\end{array}$} & \multirow[t]{3}{*}{ Sample } & \multirow{3}{*}{$\begin{array}{c}\text { Sample } \\
\text { type }\end{array}$} & \multicolumn{6}{|c|}{$\mathrm{NaCl} \%$} \\
\hline & & & & \multicolumn{2}{|c|}{$2 \%$} & \multicolumn{2}{|c|}{$4 \%$} & \multicolumn{2}{|c|}{$8 \%$} \\
\hline & & & & $24 \mathrm{hrs}$ & $48 \mathrm{hrs}$ & $24 \mathrm{hrs}$ & $48 \mathrm{hrs}$ & $24 \mathrm{hrs}$ & $48 \mathrm{hrs}$ \\
\hline 1 & $\mathrm{HCR}_{1}$ & \multirow[t]{2}{*}{ Cheese } & \multirow[t]{2}{*}{ Raw } & \multirow[t]{2}{*}{+++} & \multirow{2}{*}{+++} & \multirow[t]{2}{*}{+++} & \multirow{2}{*}{+++} & \multirow[t]{2}{*}{ \pm} & \multirow{2}{*}{-} \\
\hline 2 & $\mathrm{HCR}_{2}$ & & & & & & & & \\
\hline 3 & $\mathrm{HCP}_{1}$ & \multirow[t]{2}{*}{ Cheese } & \multirow[t]{2}{*}{ Processed } & \multirow[t]{2}{*}{+++} & \multirow{2}{*}{+++} & \multirow{2}{*}{+++} & \multirow{2}{*}{+++} & \multirow[t]{2}{*}{ \pm} & \multirow[b]{2}{*}{ - } \\
\hline 4 & $\mathrm{HCP}_{2}$ & & & & & & & & \\
\hline 5 & $\mathrm{HDR}_{1}$ & \multirow[t]{2}{*}{ Curd } & \multirow[t]{2}{*}{ Sweet } & \multirow[t]{2}{*}{+++} & \multirow[t]{2}{*}{+++} & \multirow[t]{2}{*}{+++} & \multirow{2}{*}{+} & \multirow[t]{2}{*}{ \pm} & \multirow{2}{*}{ - } \\
\hline 6 & $\mathrm{HDR}_{2}$ & & & & & & & & \\
\hline 7 & $\mathrm{HDP}_{1}$ & \multirow[t]{2}{*}{ Curd } & \multirow[t]{2}{*}{ Sour } & \multirow[t]{2}{*}{+++} & \multirow[t]{2}{*}{+++} & \multirow[t]{2}{*}{+++} & \multirow{2}{*}{++} & \multirow[t]{2}{*}{ \pm} & \\
\hline 8 & $\mathrm{HDP}_{2}$ & & & & & & & & - \\
\hline
\end{tabular}




\begin{tabular}{|c|c|c|c|c|c|c|c|c|c|}
\hline 9 & $\mathrm{HKP}_{1}$ & Milk & Processed & +++ & +++ & +++ & ++ & \pm & - \\
\hline 10 & $\mathrm{HKP}_{2}$ & Kefir & & & & & ++ & & - \\
\hline
\end{tabular}

$+++=$ more turbid, $++=$ moderately turbid, $+=$ less turbid, $\pm=$ very less turbid, $-=$ no turbidity

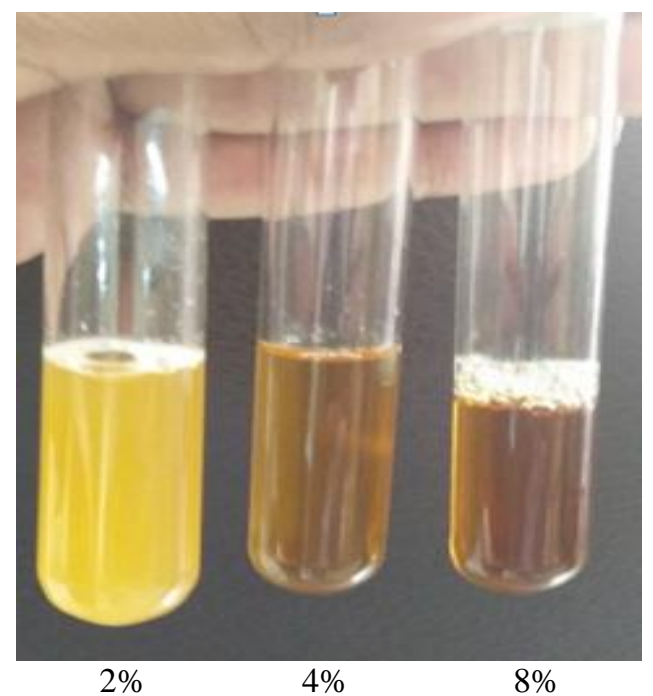

pH tolerance test:-

Figure 7: Salt tolerance test

$\mathrm{pH}$ tolerance test measures the capability of bacterial survival in acidic media and the results of $\mathrm{pH}$ tolerance study are shown in table 10 and figure 8. The entire test samples i.e. Lactobacillus species survived up to pH 3 indicatedby more turbidity of the medium by bacterial growth after 24 and 48 hours respectively. Additionally there was less to moderate turbidity at $\mathrm{pH} 4$ and no turbidity at $\mathrm{pH} 6,8$ and 10 respectively proved absence of bacterial growth at high $\mathrm{pH}$ of the medium. As extreme $\mathrm{pH}$ affects the structure of macromolecules, it broke the hydrogen bonds holding together the strands of DNA and hydrolyzed the lipids at basic $\mathrm{pH}$. If $\mathrm{H}^{+}$ions are neutralized by hydroxide ions, the concentration gradient of $\mathrm{H}^{+}$across the plasma membrane collapses and impairs energy production promoting denaturation and destroying activity thus decreasing of the rate of bacterial growth [20].

Table 10:- Observation of $\mathrm{pH}$ tolerance test

\begin{tabular}{|c|c|c|c|c|c|c|c|c|c|c|c|c|c|c|}
\hline \multirow{3}{*}{$\begin{array}{l}\text { SL. } \\
\text { No }\end{array}$} & \multirow{3}{*}{$\begin{array}{c}\text { Sample } \\
\text { code }\end{array}$} & \multirow[t]{3}{*}{ Sample } & \multicolumn{12}{|c|}{ pH } \\
\hline & & & \multicolumn{2}{|c|}{2} & \multicolumn{2}{|c|}{3} & \multicolumn{2}{|c|}{4} & \multicolumn{2}{|c|}{6} & \multicolumn{2}{|c|}{8} & \multicolumn{2}{|c|}{10} \\
\hline & & & $\begin{array}{c}24 \\
\text { hrs }\end{array}$ & $\begin{array}{c}48 \\
\text { hrs }\end{array}$ & $\begin{array}{c}24 \\
\text { hrs }\end{array}$ & $\begin{array}{c}48 \\
\text { hrs }\end{array}$ & $\begin{array}{c}24 \\
\text { hrs }\end{array}$ & $\begin{array}{c}48 \\
\text { hrs }\end{array}$ & $\begin{array}{c}24 \\
\text { hrs }\end{array}$ & $\begin{array}{c}48 \\
\text { hrs }\end{array}$ & $\begin{array}{c}24 \\
\text { hrs }\end{array}$ & $\begin{array}{c}48 \\
\text { hrs }\end{array}$ & $\begin{array}{c}24 \\
\text { hrs }\end{array}$ & $\begin{array}{l}48 \\
\text { hrs }\end{array}$ \\
\hline 1 & $\mathrm{HCR}_{1}$ & \multirow{2}{*}{$\begin{array}{c}\text { Cheese/ } \\
\text { Raw }\end{array}$} & \multirow[t]{2}{*}{+++} & \multirow[t]{2}{*}{+++} & \multirow[t]{2}{*}{+++} & \multirow[t]{2}{*}{++} & \multirow[t]{2}{*}{+} & \multirow[t]{2}{*}{ \pm} & \multirow[t]{2}{*}{-} & \multirow[t]{2}{*}{-} & \multirow[t]{2}{*}{-} & \multirow[t]{2}{*}{-} & \multirow[t]{2}{*}{-} & \multirow[t]{2}{*}{-} \\
\hline 2 & $\mathrm{HCR}_{2}$ & & & & & & & & & & & & & \\
\hline 3 & $\mathrm{HCP}_{1}$ & \multirow{2}{*}{$\begin{array}{c}\text { Cheese/ } \\
\text { Processed }\end{array}$} & \multirow[t]{2}{*}{+++} & \multirow[t]{2}{*}{+++} & \multirow[t]{2}{*}{+++} & \multirow[t]{2}{*}{++} & \multirow[t]{2}{*}{+} & \multirow[t]{2}{*}{ \pm} & \multirow[t]{2}{*}{-} & \multirow[t]{2}{*}{-} & \multirow[t]{2}{*}{ - } & \multirow[t]{2}{*}{-} & \multirow[t]{2}{*}{-} & - \\
\hline 4 & $\mathrm{HCP}_{2}$ & & & & & & & & & & & & & \\
\hline 5 & $\mathrm{HDR}_{1}$ & Curd/ & +++ & +++ & +++ & ++ & + & \pm & - & - & - & - & - & - \\
\hline 6 & $\mathrm{HDR}_{2}$ & Sweet & & & & & & & & & & & & \\
\hline 7 & $\mathrm{HDP}_{1}$ & Curd/ & +++ & +++ & +++ & ++ & + & \pm & - & - & - & - & - & - \\
\hline 8 & $\mathrm{HDP}_{2}$ & Sour & & & & & & & & & & & & \\
\hline 9 & $\mathrm{HKP}_{1}$ & Milk Kefir/ & +++ & +++ & +++ & ++ & + & \pm & - & - & - & - & - & - \\
\hline 10 & $\mathrm{HKP}_{2}$ & Processed & & & & & & & & & & & & \\
\hline
\end{tabular}

$+++=$ more turbid, $++=$ moderately turbid, $+=$ less turbid, $\pm=$ very less turbid, $-=$ no turbidity 


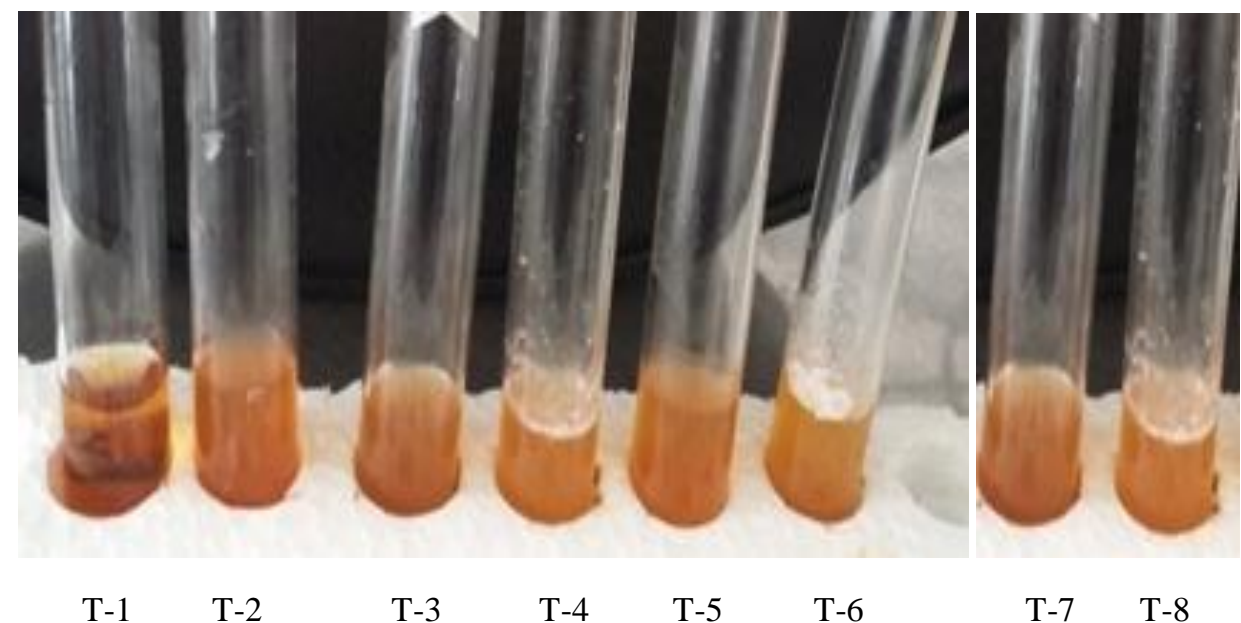

Figure 8: $\mathrm{pH}$ tolerance test

\section{Casein digestion test:-}

Skim milk agar is a differential medium that tests the ability of an organism to produce an exoenzyme, called casease that hydrolyzes the casein into smaller polypeptides, peptides and amino acids that can cross the cell membrane and be utilized by the organisms [21]. The entire test samples in casein digestion test except milk kefir, a clear zone or halo appeared around the areas where the organism had grown proved the presence of Lactobacillus species in the samples (Table 11).

Table 11:-Results of casein digestion test

\begin{tabular}{|c|c|c|c|c|}
\hline $\begin{array}{l}\text { SL. } \\
\text { No }\end{array}$ & Sample code & Sample & Sample type & Reaction with Casein \\
\hline 1 & $\mathrm{HCR}_{1}$ & \multirow[t]{2}{*}{ Cheese } & \multirow[t]{2}{*}{ Raw } & \multirow[t]{2}{*}{+} \\
\hline 2 & $\mathrm{HCR}_{2}$ & & & \\
\hline 3 & $\mathrm{HCP}_{1}$ & \multirow[t]{2}{*}{ Cheese } & \multirow[t]{2}{*}{ Processed } & \multirow[t]{2}{*}{+} \\
\hline 4 & $\mathrm{HCP}_{2}$ & & & \\
\hline 5 & $\mathrm{HDR}_{1}$ & \multirow[t]{2}{*}{ Curd } & \multirow[t]{2}{*}{ Sweet } & \multirow[t]{2}{*}{+} \\
\hline 6 & $\mathrm{HDR}_{2}$ & & & \\
\hline 7 & $\mathrm{HDP}_{1}$ & \multirow[t]{2}{*}{ Curd } & \multirow[t]{2}{*}{ Sour } & \multirow[t]{2}{*}{+} \\
\hline 8 & $\mathrm{HDP}_{2}$ & & & \\
\hline 9 & $\mathrm{HKP}_{1}$ & \multirow[t]{2}{*}{ Milk Kefir } & \multirow[t]{2}{*}{ Processed } & \multirow[t]{2}{*}{-} \\
\hline 10 & $\mathrm{HKP}_{2}$ & & & \\
\hline
\end{tabular}

\section{Acknowledgement:-}

This study was kindly supported by the Department of Pharmacy, University of Asia Pacific and funded by the Institute for Energy, Environment, Research and Development (IEERD), UAP, Dhaka, Bangladesh. 


\section{References:-}

1. Degnan, F.H. (2008): The US Food and Drug Administration and probiotics: regulatory categorization. Clin. Infect. Diseases, 46(2): 133-136

2. Roberfroid, M. B. (2000): Prebiotics and probiotics: are they functional foods? American journal of clin. nutrition, 71: 1682-1687.

3. Arora, M.and Baldi, A. (2015): Regulatory categories of probiotics across the globe: A review representing existing and recommended categorization. Indian J. of Med. Microbiol., 33(5): 2-10.

4. Stiles, M. E. and Holzapfel, W. H. (1997): Lactic acid bacteria of foods and their current taxonomy. Int. J. Food Microbiol., 36(1):1-29.

5. Rivera-Espinoza, Y. and Gallardo-Navarro, Y. (2010): Non-dairy probiotic products. Food Microbiol., 27(1): 111.

6. Greenberg A. E., Trussell R. R. and Clesceri L. S. (1985): Standard methods for the examination of water and wastewater, 16th edition., APHA, Washington, D.C

7. Cunningham, G., Seghrouchni, K., Ruffieux, E., Vaudaux, P., Gayet-Ageron, A., Cherkaoui, A., Godinho, E., Lew, D., Hoffmeyer, P. and Uçkay, I. (2014): Gram and acridine orange staining for diagnosis of septic arthritis in different patient populations. Int. Orthop., 38(6): 1283-90.

8. Wahyuni, A. E. T. H., Tabbu, C. R., Artanto, S., Setiawan, D. C. B. And Rajaguguk, S. I. (2018): Isolation, identification, and serotyping of Avibacterium paragallinarum from quails in Indonesia with typical infectious coryza disease symptoms. Vet. World., 11(4):519-524.

9. Ryck, R. D.,Struelens, M. J. and Serruys, E. (1994): Rapid biochemical screening for Salmonella, Shigella, Yersinia, and Aeromonas isolates from stool specimens. J. Clin. Microbiol., 32(6): 1583-5.

10. Sheikh, A. F., Yadyad, M. J., Goodarzi, H., Hashemi, S. J., Aslani, S., Assarzadegan, M. A. and Ranjbar, R. (2018): CagA and vacA allelic combination of Helicobacter pylori in gastroduodenal disorders. Microb. Pathog., 20(122): 144-150.

11. Brown, A. and Smith, K. (2015): Benson's microbiological applications, laboratory manual in general microbiology, 13th edition, pp 277.

12. Promon, S. K., Kamal, W., Rahman, S. S., Hossain, M. M. and Choudhury, N. (2018): Bioethanol production using vegetable peels medium and the effective role of cellulolytic bacterial (Bacillus subtilis) pre-treatment. Version, 7:271.

13. Aarti, C., Khusro, A., Varghese, R., Arasu, M. V., Agastian, P., Al-Dhabi, N.A., Ilavenil, S. and Choi, K. C. (2018): In vitro investigation on probiotic, anti-candida, and antibiofilm properties of Lactobacillus pentosus strain LAP1. Arch. oral. biol., 89: 99-106.

14. Delekta, P. C., Shook, J. C., Lydic, T. A., Mulks, M. H. and Hammer, N. D. (2018): Staphylococcus aureus utilizes host-derived lipoprotein particles as sources of exogenous fatty acids. J. Bacteriol., 26:717-28.

15. Fisk, R. T. and Mordvin E. O. (1943): Digestion of casein by staphylococci on milk agar containing serum. J. Bacteriol., 46(4): 392-393.

16. Brown, A. and Smith, K. (2015): Benson's Microbiological Applications, Laboratory Manual in General Microbiology. 13th edition, pp 277.

17. Pyar, H. and Peh, K. K. (2014): Characterization and identification of Lactobacillus acidophilus using biology rapid identification system. Int. J. Pharm. and Pharm Sci., 6(1): 189-193.

18. Hossain, M. S., Al-Bari, A. and Wahed, M. I. I. (2016): Biochemical characterization of probiotics available in Bangladesh. J. of Sci. Res., 8(1): 101.

19. Hajna, A. A. and C. A. Perry. (1943): Comparative study of presumptive and confirmative media for bacteria of the coliform group and for fecal Streptococci. A. J. of Pub. Health, 33:550-58.

20. Sahadeva, R. P. K., Leong, S. F., Chua, K. H., Tan, C. H., Chan, H.Y., Tong, E.V., Wong, S.Y.W. and Chan, H.K. (2011): Survival of commercial probiotic strains to pH and bile. I. F. Resh. J., 18(4): 1515-1522.

21. Thakur, M., Deshpande, H. M. and Bhate, M. A. (2017): Isolation and identification of lactic acid bacteria and their exploration in non-dairy probiotic drink. I. J. of C. Micro. and Apl. Sci., 6(4):1023 -1030. 